\title{
Wetlands and diversity of angiosperm macrophytes in wetlands of Pune district in Maharashtra, India
}

\author{
Savita S. Rahangdale ${ }^{1} \&$ Sanjaykumar R. Rahangdale ${ }^{2^{*}}$ \\ ${ }^{1}$ Department of Botany, Hon. Balasaheb Jadhav College, Ale, Dist. Pune, 412 411, Maharashtra, India \\ ${ }^{2}$ Department of Botany, Annasaheb Waghire College, Otur, Dist. Pune, 412 409, Maharashtra, India \\ *Email: rsanjay2@hotmail.com
}

\section{ARTICLE HISTORY}

Received: 24 June 2020

Accepted: 27 October 2020

Published: 01 January 2021

\section{KEYWORDS}

Wetlands; plateau; status categories; species richness; hydrophytes

\section{ABSTRACT}

The wetlands and wetland macrophytes play crucial role in the ecosystem with direct as well as indirect benefits of uncountable value. A study was undertaken to document angiospermic wetland macrophytes in Pune district, Maharashtra state, India. Results of the study revealed that, there are 11 categories of wetlands in Pune district including seven natural and four man- made. These wetlands harbour 457 angiosperms belonging to 72 families. Of these, 457 taxa, 204 taxa are under different categories as per IUCN, while 253 are not evaluated. Among recorded taxa, one is 'Critically Endangered' (Eriocaulon santapaui), three 'Endangered' (Iphigenia stellata, Eriocaulon richardianum and Dimeria hohenackeri), two 'Vulnerable' (Isachne bicolor and Utricularia albocaerulea) and 198 taxa are 'Least concerned'. Total 67 Indian endemic taxa are recorded from the wetlands in the study area.

\section{Introduction}

Aquatic systems include deep-water systems and wetlands. Deep-water systems include big rivers, lakes and water reservoirs which have more than $2 \mathrm{~m}$ depth of water, while the systems with partial/seasonal/perennial shallow submergence are called wetlands (1). The wetlands generally found in ecotones between deep water systems and terrestrial ecosystems. The wetlands may have at least one or more following attributes: i) at least for certain period of a year the hydrophytes are predominant on such land; ii) undrained hydric soil is the predominant substrate; iii) in each year at some time during the growing season the substrate is nonsoil and saturated with water or covered by shallow water level (2). A very simple definition of a wetland is, 'wetlands are those ecosystems or ecotones which are dominated by macrophytes' (3). As per the Ramsar information paper on wetlands, 'the wetlands are areas where water is the primary factor controlling the environment and the associated plant and animal life. They occur where the water table is at or near the surface of the land, or where the land is covered by water' (4).

The macrophytes are inseparable entity of shallow wetlands. Macrophytes fulfil different needs of the other biotic components of the system. They provide food and oxygen as well as shelter to associated biota. They also work as a sink for organic as well as inorganic elements present in the ecosystem. They are important as a resource provider in the form of nutrient-rich foods and medicines to human communities. They filter the water, recycle the nutrients and produce humus due to fast decomposition of biomass and also work as significant carbon sinks in wetland systems. The wetlands are vital aquifers to recharge ground water table; therefore, they are of immense importance to human society (4).

The documentation of floristic diversity of any region is of immense importance to utilize and conserve the resources as well as to protect the interests of the society and nation at large (5). In India documentation of biodiversity especially phytodiversity is done to a great extent in general. In India,

(C) Rahangdale \& Rahangdale (2021). This is an open-access article distributed under the terms of the Creative Commons Attribution License, which permits unrestricted use, distribution and reproduction in any medium, provided the original author and source are credited (https://creativecommons.org/licenses/by/4.0/).

To cite this article: Rahangdale S S, Rahangdale S R. Wetlands and diversity of angiosperm macrophytes in wetlands of Pune district, in Maharashtra, India. Plant Science Today. 2021;8(1):16-23. https://doi.org/10.14719/pst.2021.8.1.849 
a few significant wetlands such as Sundarbans, Dal Lake, Chilika Lake and Ramsar sites are extensively studied with respect to diversity of biota, physicochemical properties and social relevance (1). An attempt to report aquatic vegetation of the Indian subcontinent and their composition was made by Lavania and co-workers (6). An earlier study provides classification of wetlands in India (1). Cook (7) provided a comprehensive manual for identification of aquatic plants of India. Though this is comprehensive documentation, there is very less information available about the regional wetlands. Physical factors affecting the macrophytic vegetation were evaluated (8). The limnological parameters like light, $p H$, nitrogen content of water and its effect on presence of tropical hydrophytes were reported (9); while a review of factors affecting distribution patterns of aquatic macrophytes is done (10). National Wetland Atlas identified 201503 wetlands of more than 2.25 ha size across all the states of India and classified the wetlands into 19 classes (11). As for Maharashtra state, NWA (11) identified 23046 wetlands across the state; of these only four viz., Jayakwadi, Ujani and Nalganaga wetlands and recently identified Ramsar site of NandurMadhmeshwar are recognized by MoEF \& CC as significant wetlands in Maharashtra (12). In the addendum to NBAP (13) it is emphasized to strengthen research work on protected areas, fragile ecosystems and wetlands to develop baseline data on biological and managerial parameters and functional properties of ecosystems. It has given priority for development of strategies for protection and conservation of wetlands with the use of their resources involving local communities and other stakeholders.

Documentation of wetland flora of Maharashtra is done to some extent and is evident from State Gazetteer (14) reported 125 aquatic angiosperms of Maharashtra. In an inventory of hydrophytes of Maharashtra 279 species, 4 subspecies and 12 varieties were reported (15). From South-western Maharashtra 303 aquatic angiosperms from fresh water as well as mangrove wetlands are reported from four districts, viz., Satara, Kolhapur, Ratnagiri and Sindhudurg (16). Sporadic reports of small reservoirs or riverine ecosystems are available, especially from Vidarbha region of the state $(17,18)$. The Flora of Maharashtra (19) recorded only a glimpse of hydrophytes and mangroves of Maharashtra state in general, but the plant diversity of wetlands was not emphasized. Even in the revised state gazetteer (20) the wetland plants, as well as the hydrophytes are neglected and a very scanty information is provided about the wetland plants. Critical notes on distribution patterns of aquatic plants especially those are endemic and threatened in the Western Ghats is given in a report of IUCN, but without total list of aquatic plants of Western Ghats (21). This report also emphasized that the studies on aquatic plants are very negligible as compared to the plants of other ecosystems. Same is the case with wetlands of Maharashtra state except for the coastal systems. Though there are several reports of floristic diversity from Pune region (22-28); all are confined to general vegetation and flora with the main emphasis of diversity of angiosperms. The reports related to aquatic or wetland plants are very less. Wetland plants of Mutha riverbed near Pune (29) and later 74 macrophytes are reported from Mula river in Pune city (30). Recent reports from the region provided structure and composition of wet microhabitats on the high altitude plateaux and plants associated with these microhabitats (31-33). All these evidences showed that, the comprehensive reports with special reference to the aquatic ecosystems of the region are not available. Therefore, a study was undertaken to bring on records the wetland ecosystems and the diversity of angiospermic wetland macrophytes in the district Pune.

\section{Materials and Methods}

\section{Study area}

The district Pune is geographically located between $17.5^{\circ}$ to $19.2^{\circ} \mathrm{N}$. latitude and $73.2^{\circ}$ to $75.1^{\circ} \mathrm{E}$. longitude with a total area of $15642 \mathrm{~km}^{2}$. The district is bounded by Thane district on the north-west, Raigad district on the west, Satara district on the south, Solapur on the south-east and Ahmednagar district on the north and north-east. In the west it has high hills of Western Ghats in the form of Sahyadri and it extends to the Deccan plateau on the east. The physiography is varied with altitudinal variations from about $600 \mathrm{msl}$ to $1300 \mathrm{msl}$. There are fourteen rivers with twenty reservoirs/dams of small and medium capacity, and several many small local reservoirs constructed mainly to fulfil agriculture, industrial and domestic water demands. There are canals with most of the reservoirs further increasing wet areas. Main rivers are Neera, Mula-Mutha and Ghod-Bhima with their tributaries. Important reservoirs are Neera-Devghar, Bhatghar, Veer, Panshet, Varasgaon, Valvhan, Khadakwasala, Mulashi, Pawana, Chas-Kaman, Dimbhe, Wadaj, Manikdoh, Pimpalgaon Joge, Yedgaon and Ujani (partial backwaters). These dams and their backwaters are large wetlands with great anthropocentric activities and influences. As per National Wetland Atlas, Maharashtra; about 4.36\% of the total geographic area of the district is identified as wetlands (Fig. 1) including free water area (11).

\section{Data Collection}

Extensive and repeated field surveys were carried out from 2010 to 2018 in the study area, covering all the seasons of the year to document the species richness of the wetlands in study area. A comprehensive list of angiospermic macrophyte taxa occuring in wetlands in the area under study is prepared. During field surveys, emphasis was given to document type of vegetation, habitat, growth form, phenology and associated species if any. Monsoon ephemerals, tuberous, cormatous and rhizomatous plants with a short life span were given special attention to get data on their life cycle and phenology especially on the plateau ecosystems. Morphological characters were recorded on the basis of fresh material in the field. 


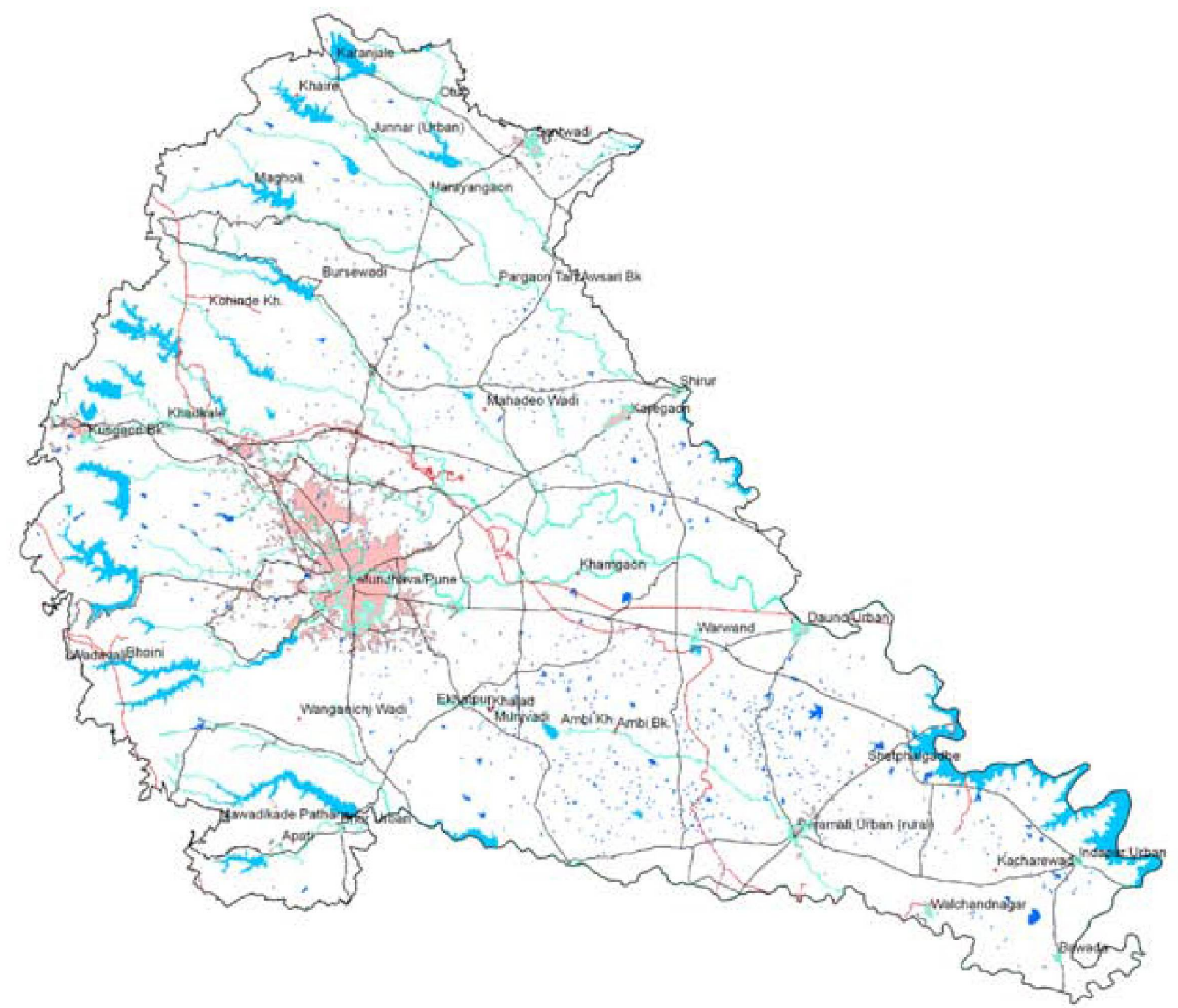

Fig. 1. Study area showing wetlands (Blue areas are wetlands) adapted from National Wetland Atlas : Maharashtra, SAC/RESA/AFEG/NWIA/ ATLAS/19/2009. (https://www.saconenvis.nic.in/publication\%255CNWIA_National_atlas.pdf).

\section{Laboratory Studies}

Collected plant specimens were processed for the herbarium following standard techniques (34). In most of the cases, specimens were identified afresh. All the herbarium specimens were carefully checked in the laboratory and their identity was confirmed with help of the floras $(19,22,23,25,35-43)$ and published literature in scientific journals. Doubtful specimens were checked and confirmed by comparing with earlier identified specimens at the following herbaria: (i) Botanical Survey of India, Western Circle, (BSI), Pune, (ii) Agharkar Herbarium (AHMA), Agharkar Research Institute, Pune. Voucher specimens are deposited in the Herbarium of Balasaheb Jadhav College, Ale.

The taxonomic treatment of the taxa follows APG IV system of classification (44). Nomenclatural updates are as per Plants of the World Online database (45) and the Plant list database (46). The threat status of each taxon is provided as per the IUCN Red List (47). The status categories of the macrophytes of wetlands are followed (48). As there is no proper classification of the wetlands of study area was available. The areas are classified as per the earlier work $(1,2)$. The characteristic features of classified wetlands are provided in Table 1.

\section{Results and Discussion}

\section{The wetlands}

The wetlands in study area are mainly of three types, i) Lacustrine (wetlands associated with lakes/reservoirs) (Fig. 3), ii) Riverine (wetlands along rivers and streams) and iii) Palustrine (marshes, swamps and bogs). Palustrine wetlands in the district are of seasonal marshes on plateau and alongside canals and sugarcane fields. The wetlands in Pune are classified and found that, there are seven categories of natural wetlands and four categories of artificial/man-made wetlands (Table 1). Most of the natural wetlands are distributed in high elevation plateau (Fig. 4). The highest diversity of macrophytes is recorded in natural wetlands. Artificial wetlands are less in number and of perennial nature such as backwater areas of reservoirs like Yedgaon, Mulashi, Ujani, Pimpalgaon-joga etc. Macrophyte community in these habitats is usually dominated by invasive and opportunistic taxa like, Ipomoea carnea Jacq., Typha angustifolia L., Chrozophora rottleri (Gies.) Juss., Persicaria glabra (Willd.) Gomez., Alternanthera sessilis (L.) R. Br. ex DC. etc. 


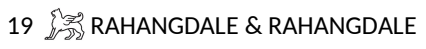

Table 1. Classification of wetlands recorded in Pune district.

\begin{tabular}{|c|c|c|c|}
\hline Category & Type & Wetland & Features \\
\hline \multirow{7}{*}{ Natural } & \multirow{3}{*}{ Riverine } & Waterfalls & Seasonal, generally in the hills and along slopes \\
\hline & & Riverbanks & Along river course \\
\hline & & Shallow flowing water & $\begin{array}{l}\text { Near the origin of rivers, shallow flowing water stream beds and } \\
\text { vegetation along with its margins }\end{array}$ \\
\hline & \multirow{4}{*}{ Palustrine } & Plateau & Flat topped hills with seasonal saturation of water \\
\hline & & Seasonal marshes & $\begin{array}{l}\text { Ephemeral marshes are observed along the plateau, and associated } \\
\text { forests fringes }\end{array}$ \\
\hline & & Seasonal ephemeral pools & Small poodles along the plateau as well as at low elevation \\
\hline & & Seasonal runoffs & Rain water runoff paths on the plateau \\
\hline \multirow{4}{*}{ Man-made } & Lacustrine & Dams / reservoirs & $\begin{array}{l}\text { Water reservoirs constructed for irrigation and flood control. It has } \\
\text { shallow water and terrestrial habitats }\end{array}$ \\
\hline & \multirow{3}{*}{ Palustrine } & Canals & Along the plains and fields and also have water seepage along canals \\
\hline & & \multicolumn{2}{|c|}{ Rice fields \& Sugarcane fields Original marshy places converted to rice fields } \\
\hline & & Abandoned quarries & After excavation of minor ores, such quarries are water logged \\
\hline
\end{tabular}
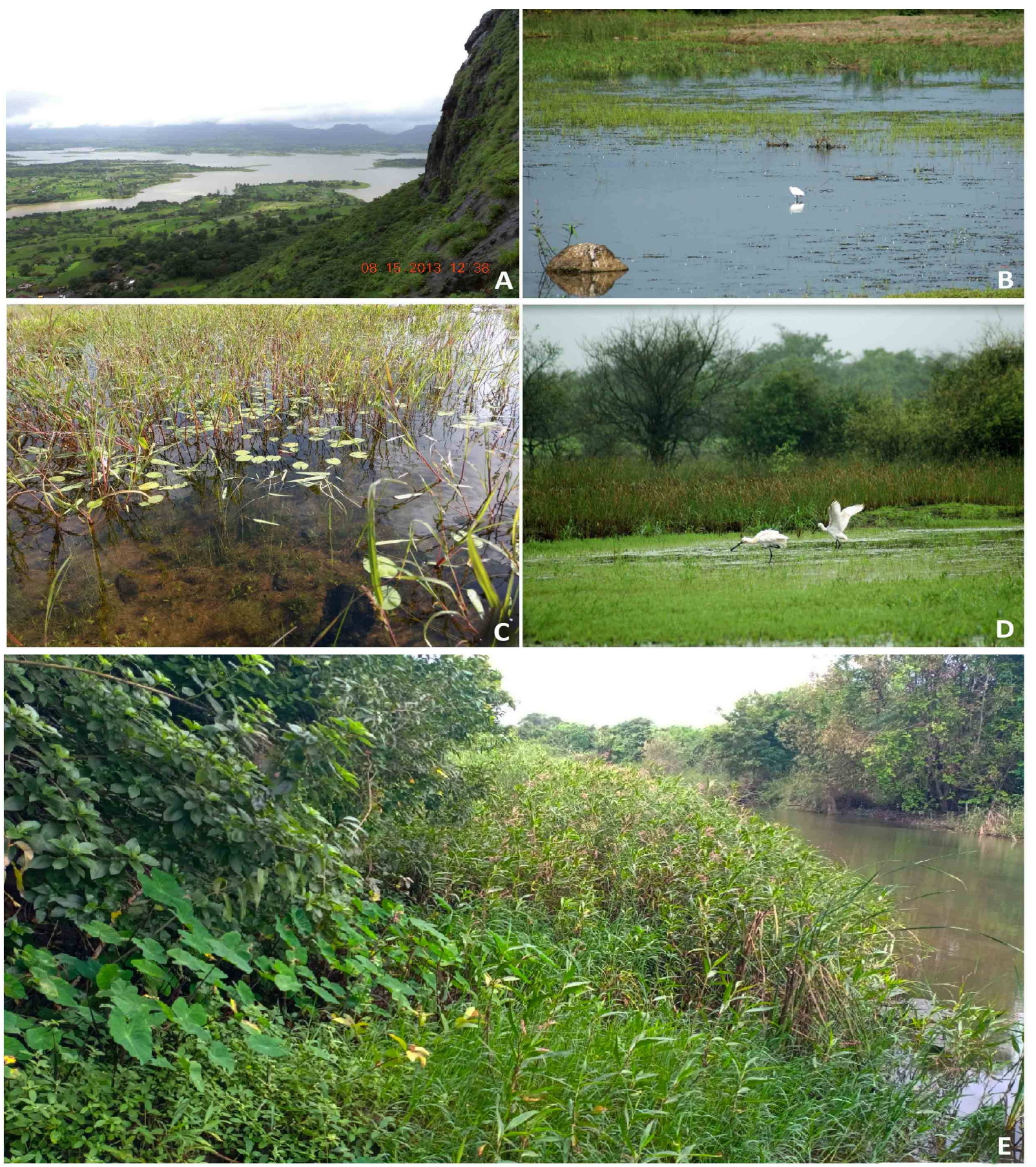

Fig. 3. Wetlands in study area : A. Backwaters of Manikdoh reservoir during rainy season; B. Backwater marsh of Khadakwasala; C. Hydrophyte community along the margin of pond; D. Marsh vegetation near Pimpalgaon Joga; E. Macrophytes of riverine wetland. 

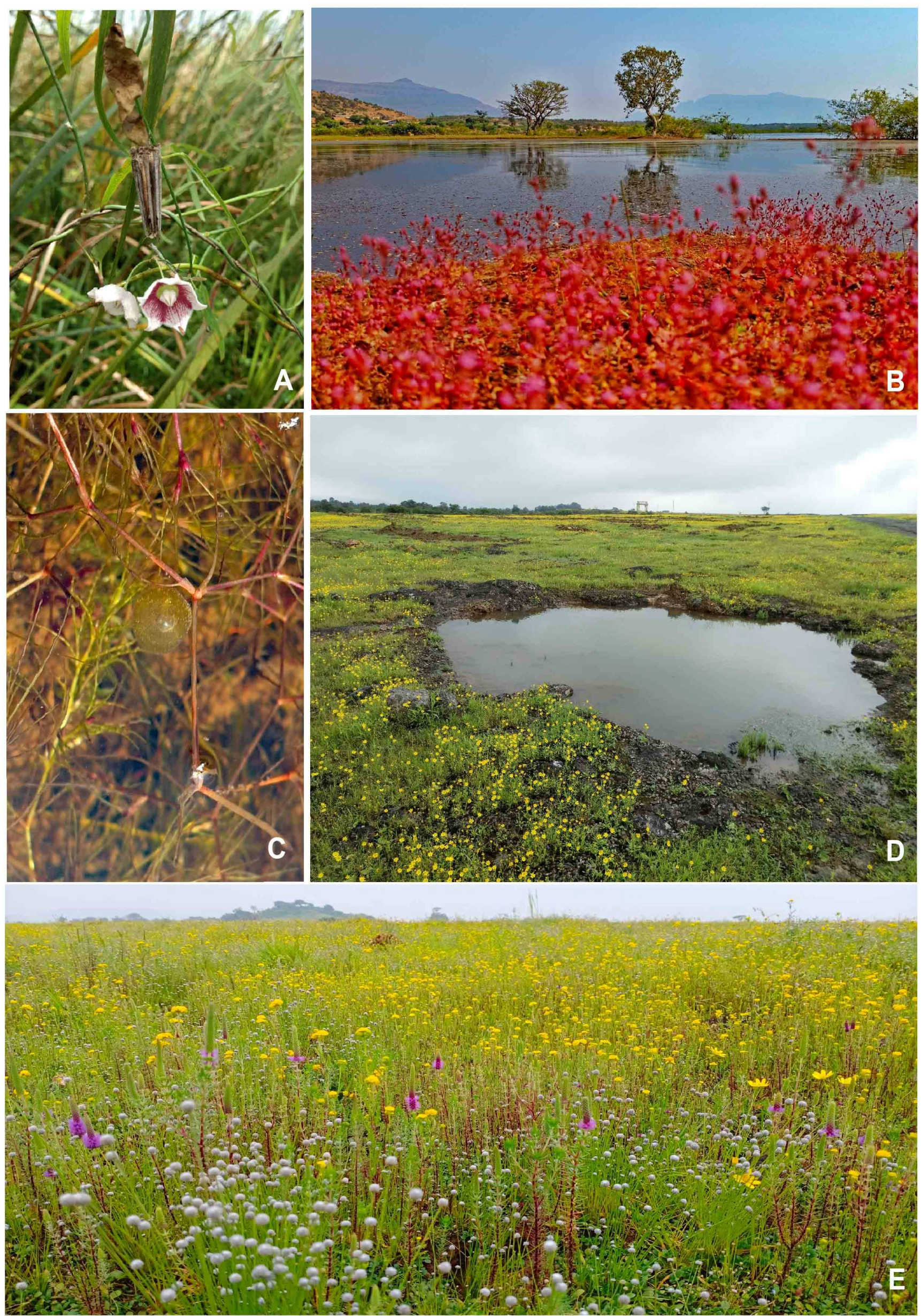

Fig. 4. A. Oxystelma esculentum on Typha in riverine marsh; B. Marshy area with Rotala sp. in foreground; C. Najas indica submerged in shallow water; D. Seasonal pool on plateau with dominance of Senecio spp; E. Macrophytes at plateau comprising Eriocaulon-PogostemonSenecio-Cyathocline community. 


\section{Macrophyte Diversity}

The species richness of angiospermic macrophytes in the wetlands of Pune district comprises 457 taxa at species and infraspecific level (Supplementary Table 1). As per APG IV system they are distributed under 72 families and 28 orders. As the wetlands are vulnerable to anthropogenic activities, the plants occurring there also face threats. Among these 457 taxa, 204 taxa are under different categories as per IUCN, while 253 are not evaluated. Among evaluated taxa, one is 'Critically Endangered' (Eriocaulon santapaui Moldenke), three 'Endangered' (Iphigenia stellata Blatt, Eriocaulon richardianum (Fyson) R.Ansari \& N. P. Balakr. and Dimeria hohenackeri Hochst. ex Miq.), two 'Vulnerable' (Isachne bicolor Naik \& Patunkar and Utricularia albocaerulea Dalz.) and 198 taxa are 'Least concerned' as per IUCN. Among the recorded taxa, 67 are Indian endemics.

While assessing the wetland flora on the basis of frequency of occurrence of the taxa as hydrophyte or non-hydrophyte, there are five different status categories. These categories are, i) OBL- obligate wetland species which almost always occur as hydrophyte and very rarely in uplands/terrestrial habitats; ii) FACW- Facultative wetland species usually a hydrophyte but occasionally found in uplands/terrestrial habitats; iii) FAC- Facultative species occurs either as hydrophyte or nonhydrophyte; iv) FACU- Facultative upland species, which occurs as usual terrestrial and occasional hydrophyte; and v) UPL- Obligate upland species which is almost always a non-hydrophyte (48). In the present study, out of 457 recorded taxa, 92 are obligate wetland plants (OBL), 257 are facultative wetland plants (FACW), 21 are facultative taxa (FAC), 25 facultative upland species (FACU) and 62 upland species (UPL) (Fig. 2).

It is observed that, most of the wetlands at high elevation plateau are dominated by members of Poaceae and Cyperaceae families with seasonal dominance of OBL and FACW taxa (Fig. 5). There is quick seasonal succession of plant communities as per availability of water. The initial community of Curculigo, Hypoxis, Iphigenia dominating at the beginning of monsoon is replaced during late monsoon by Eriocaulon, Smithia, Drosera, Utricularia and then followed by Pogostemon, Linum, Senecio, Cyperus, Grasses community in the post-monsoon period.

Similarly, in the lacustrine wetlands the Eriocaulon, Dopatrium, Commelina, Murdannia, Lindernia community in the monsoon is replaced by Ammania, Echinocloa, Pogostemon, Cyperus community in late monsoon period. Further, Canscora, Sphaeranthus, Centaurium, Exacum, Alternanthera, Bacopa, Lindernia dominates during the winter season.

Regarding distribution of taxa, the most widely distributed taxa are Typha angustifolia L., Echinochloa colona (L.) Link, Ipomoea carnea Jacq., Limnophila heterophylla (Roxb.) Benth., Ottelia alismoides (L.) Piers, Vallisneria spiralis L., Hydrilla verticillata (Linn. f.) Royle, Canscora diffusa (Vahl) R.

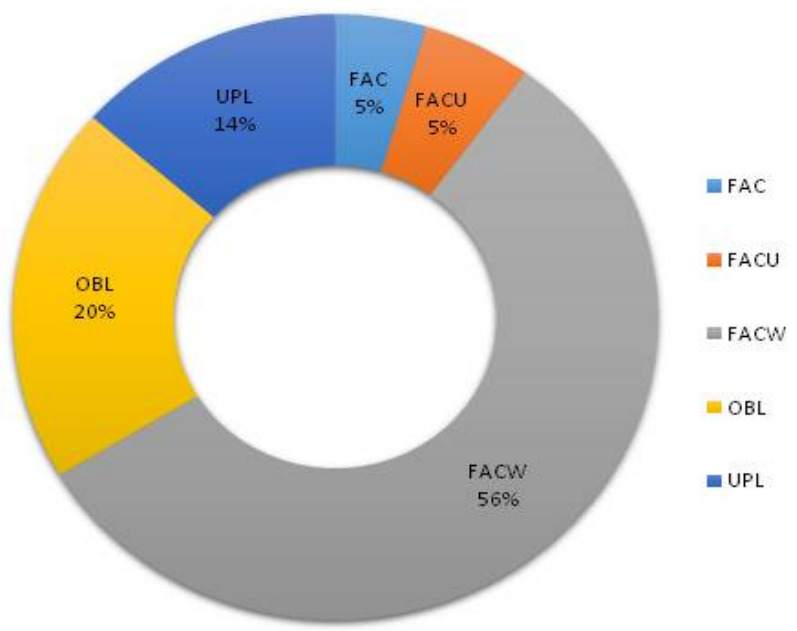

Fig. 2. Extent of wetland plants as per status categories.

Br. ex R. \& S. and Hygrophila auriculata (Schumach.) Heine. The taxa with restricted distribution are, Canscora concanensis C.B.Cl., Cleome rutidosperma DC., Cyathocline lutea Law ex Wight, Drosera burmanni Vahl, Oxystelma esculentum (L.f.) R.Br., Utricularia janarthanamii S.R. Yadav, Sardesai \& S.P. Gaikwad, U. arcuata Wight etc. The free-floating forms viz., Pistia stratiotes L. and Pontederia crassipes Mart. are found only in the riverine habitats where water is polluted by urban household sewage disposal. Such sites also have Paspalum and Alternanthera species forming mats on marshes along margins.

\section{Conclusion}

The wetlands of district Pune are of riverine, palustrine and lacustrine types. Total 11 categories of freshwater wetlands are identified and classified. The species richness of angiospermic taxa in wetlands is recoreded for first time for study area. The species richness comprises 457 angiosperms belonging to 72 families and 28 orders as per APG IV system.

\section{Acknowledgements}

Authors are thankful to the Department of forests, Government of Maharashtra for support in the surveys. Support from Botanical Survey of India, Western Regional Centre (BSI), Pune and Agharkar Research Institute, Pune for access to library and Herbarium facilities are acknowledged with due respect. Authors duly acknowledge the authorities of respective institutions for laboratory facilities and support.

\section{Authors' contributions}

SSR has done the confirmation of identity of the specimens collected, analytical work of this study and presentation of the results and discussion. SRR has done the field work, collection and processing of samples, morphological characterization of the taxa and manuscript editing. Both the authors read and approved the final manuscript. 

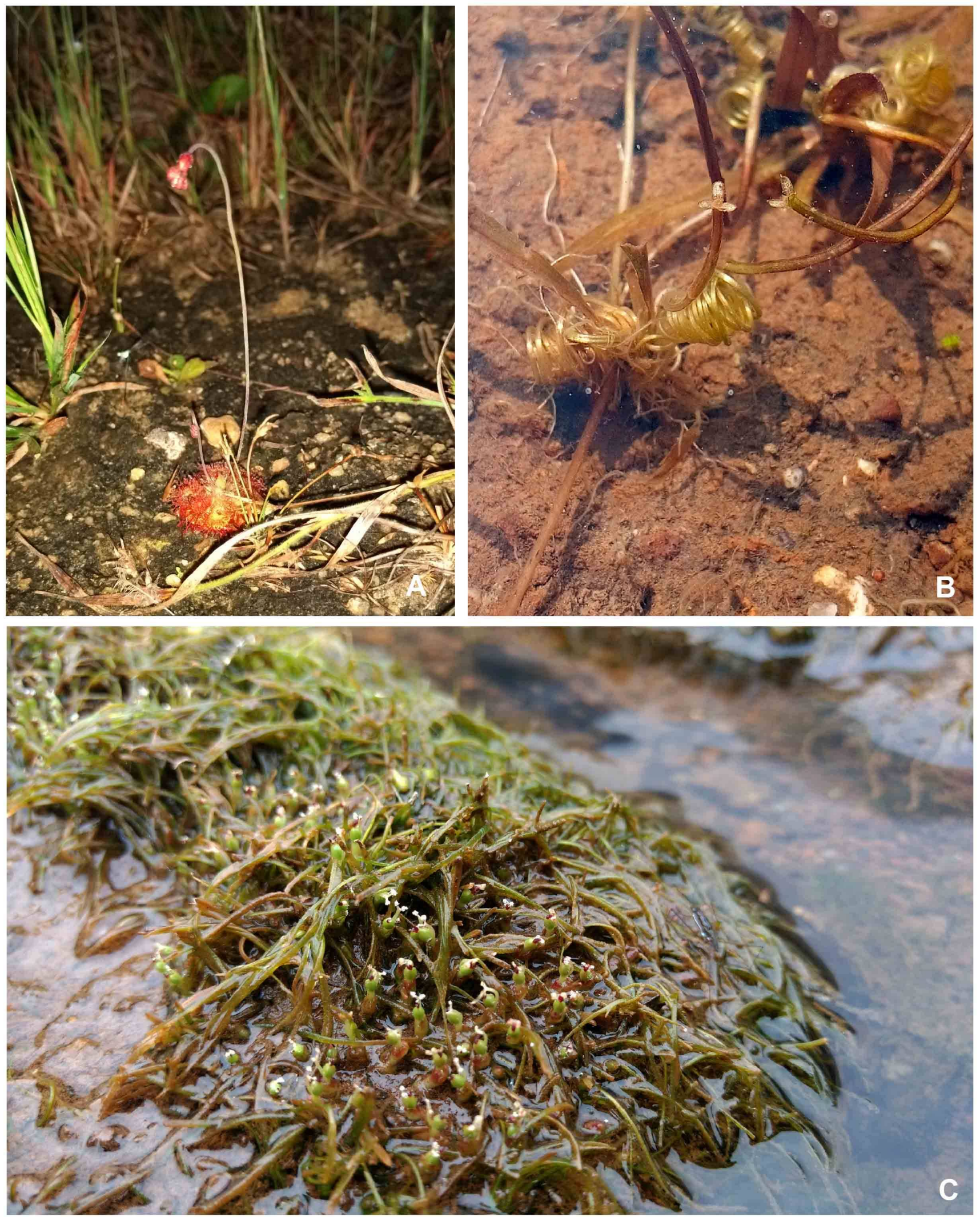

Fig. 5. A. Drosera burmannii among grasses on plateau; B. Vallisneria spiralis in shallow water; C. Zeylanidium lichenoides on rock in stream.

\section{Conflict of interests}

Authors do not have any conflict of interests to declare.

\section{Supplementary files}

Table 1. Aquatic macrophytes recorded from Pune district.

\section{References}

1. Gopal B, Sah M. Inventory and classification of wetlands in India Vegetatio 1995; 118(1\&2):39-48. https://doi.org/10.1007/BF00045189

2. Cowardin LM, Carter V, Golet EC, La Roe. Classification of wetlands and deep water habitats. 109pp. Washington D.C., USFWS/085-79/31, Office of the Biological Services, U.S. Fish and Wildlife Service; 1979.

3. Gopal B. Should wetlands cover all aquatic ecosystems and do macrophytes make difference to their ecosystem services? Folia 
Geobotanica 2016; 51(3):209-26. https://doi.org/10.1007/s12224-0169248-x

4. Ramsar Information Paper No. 1. What are wetlands? 18 Jan. 2007. Available from www.ramsar.org/sites/default/files/documents/ibrary/info2007-01e.pdf.

5. NBAP. National Biodiversity Action Plan. 104 pp. New Delhi: Government of India, Ministry of Environment and Forests; 2008. Available from www.moef.nic.in

6. Lavania GS, Paliwal SC, Gopal B. Aquatic vegetation of the Indian subcontinent. In: Gopal E. (editor). Ecology and Management of the Aquatic Vegetation of the Indian subcontinent. Dordrecht: Kluwer Academy Publishers. 1990. p.29-78. https://doi.org/10.1007/978-94 009-1984-6_3

7. Cook CDK. Aquatic and wetland plants of India. 385pp. Oxford: Oxford University Press; 1996.

8. Unni KS. An ecological study of the macrophytic vegetation of the Doodhadhari lake, Raipur, MP., India. 2. Physical factors. Hydrobiologia https://doi.org/10.1007/BF00036554

1971;38(3-4):479-87.

9. Mukhopadhyay G, Dewanji A. Presence of tropical hydrophytes in relation to limnological parameters - a study of two freshwater ponds in Kolkata, India. International J Limnology.2005;41(4):281-89. https://doi.org/10.1051/limn/2005019

10. Dar NA, Pandit AK, Ganai BA. Factors affecting the distribution patterns of aquatic macrophytes. Limnology Review.2014;14(2):7581. https://doi.org/10.2478/limre-2014-0008

11. NWA. National Wetland Atlas, SAC/RESA/AFEG/NWIA/ATLAS/19/2009. 222pp. Ahmedabad: Space Applications Centre (ISRO), India; 2010. Available from http://saconenvis.nic.in/publication\%255CNWIA_National_atlas.pdf

12. Anonymous. State-wise list of wetlands in India. ENVIS, MoEF \& CC, Government of India. [Internet]. 2020 April 4. Available from http:// www.wwfenvis.nic.in/Database/StatewiseListofWetlandsinIndia_4470.aspx?

13. NBAP.National Biodiversity Action Plan, Addendum 2014 to NBAP 2008. 88pp. New Delhi: Government of India, Ministry of Environment and Forests; 2014. Available from www.moef.nic.in

14. Mahabale TS. Botany and Flora of Maharashtra. pp. 825-829. Maharashtra State Gazetteer, Government of Maharashtra; 1987.

15. Karthikeyan S, Anand Kumar, Sharma BD. Aquatic angiosperms of Maharashtra. J Econ Taxon Botany. 1982; 3:423-45.

16. Gaikwad SP, Sardesai MM, Yadav SR. Aquatic flowering plant wealth of South-Western Maharashtra. Bull Bot Surv India. 2004;46(1 4):196-215.

17. Ugemuge NP. Flora of Nagpur district. 497pp. Nagpur: Sree Prakashan; 1986.

18. Reddy BM, Chaturvedi A. Study of aquatic and associated macrophytes from the major rivers of the Chandrapur district, Maharashtra. International J Sci. Environ \& Tech. 2016;5(6):37743782 .

19. Singh NP, Karthikeyan S, (editors). Flora of Maharashtra State, Dicotyledons Vol I. 898pp. Calcutta: Botanical Survey of India; 2000.

20. Naik VN. Maharashtratil Vanaspatishastra aani Vansampada 611pp. Maharashtra State Gazetteer, Government of Maharashtra; 2006. (Marathi).

21. Brawin Kumar R, Anitha K, Watve A, Mani S, Rehel S, Arisdason W. The status and distribution of aquatic plants of the Western Ghats. In: Molur S, Smith KG, Daniel BA, Darwall WRT Compilers. The Status and Distribution of Freshwater Biodiversity in the Western Ghats, India. Cambridge, UK and Gland, Switzerland: IUCN and Coimbatore, India: Zoo Outreach Organisation; 2011. P. 73-85. Available from www.iucn.org

22. Santapau H. The Flora of Purandhar. 159pp. Oxford: Oxford Publication; 1957.

23. Santapau H. The Flora of Khandala on Western Ghats of India. Records of Botanical Survey of India 1960; 16(1):1-369.
24. Janardhanan KP. The Flora of Bhimashankar and surrounding areas of Khed Taluka, Poona. District, Maharashtra State Vol I \& II. Doctor of Philosophy [Thesis]. Pune: Poona University; 1966.

25. Hemadri K. The Flora of Junnar and Surroundings, Poona District, Maharashtra State Vol I \& II. Doctor of Philosophy [Thesis]. Pune: Poona University; 1970.

26. Rahangdale SS. Status of floristic diversity of Junnar with special reference to impact of developmental activities. Vol I \& II. Doctor of Philosophy [Thesis]. Pune: University of Pune; 2008.

27. Bhagat RB, Shimple VB, Deshmukh RB. Flora of Baramati. 449pp. 2008.

28. Bhagat RB. Floristic diversity of Mulshi. 297pp. SERB; 2018.

29. Vartak VD. The study of flora of the Mutha river-bed near Poona. Poona Agric College Magazine 1958;48(4):24-40; \& 49(1):121-32.

30. Kshirsagar AD, Gunale VR. Diversity of aquatic macrophytes from River Mula, Pune City, MS, India. Science Research Reporter 2013;3(1):09-14.

31. Rahangdale SS, Rahangdale SR. Plant species composition on two rock outcrops from the northern Western Ghats, Maharashtra, India. J Threatened Taxa 2014; http://doi.org/10.11609/JoTT.o3616.5593-612

32. Rahangdale SS, Rahangdale SR. Floristic diversity of Bhimashankar Wildlife Sanctuary, Northern Western Ghats, Maharashtra, India. J Threatened Taxa 2017;9(8):10493-527. http://doi.org/10.11609/jott.3074.9.8.10493-10527

33. Rahangdale SR, Rahangdale SS. Biodiversity of Durgawadi Plateaus 114pp. Mumbai: Government of Maharashtra: Department of Forests;2018.

34. Jain SK, Rao RR. Field \& Herbarium Methods. 157pp. Delhi: Today \& Tomorrow’s Printers \& Publishers; 1977.

35. Hooker JD. The Flora of British India - Volumes 1-7. London. 18721897. (Dehradun: Bishen Singh Mahendra Pal Singh, Reprint 2006).

36. Cooke T. The Flora of the Presidency of Bombay - Volumes $1 \& 2$. London;1901-08.

37. Sharma BD, Karthikeyan S, Singh NP (editors). Flora of Maharashtra State, Monocotyledons. Calcutta: Botanical Survey of India; 794pp. 1996.

38. Singh NP, Lakshminarasimhan S, Karthikeyan S, Prasanna PV (editors). Flora of Maharashtra State, Dicotyledons - Volume 2. Calcutta: Botanical Survey of India; 1080pp. 2001.

39. Almeida MR. Flora of Maharashtra - Volume 1. Mumbai: Orient Press; 294pp. 1996

40. Almeida MR. Flora of Maharashtra - Volume 2. Mumbai: Orient Press; 457pp. 1998.

41. Almeida MR. Flora of Maharashtra - Volume 3. Mumbai: Orient Press; 567pp. 2001.

42. Almeida MR. Flora of Maharashtra - Volume 4. Mumbai: Orient Press; 471pp. 2003.

43. Almeida MR. Flora of Maharashtra - Volume 5. Mumbai: Orient Press; 495pp. 2009.

44. APG IV. An update of the angiosperm phylogeny group classification for the orders and families of flowering plants: APG IV. Bot Linnean Society 2016;181:1-20. https://doi.org/10.1111/boj.12385

45. POWO. Plants of the world online. [Internet]. 2020 June 5. Available from http://www.plantsoftheworldonline.org

46. Plant List. The Plant List. [Internet]. 2020 April 13. Available from http://www.theplantlist.org/

47. IUCN. IUCN Red List. [Internet]. 2020 June 16. Available from https:// www.iucnredlist.org/search/stats?query=Murdannia\%20spira \%20\&searchType=species

48. Carpenedo SM, Saul LA. Common native and invasive wetland plants in Montana, Ver 2. [2020 Jun 5] pp.121. Helena, MT: Montana department of Environmental Quality, Wetland Program; 2012. Available from: https://www.mtnhp.org/wetlands/docs/WetlandPlantBook.pdf 